\title{
- vírus e o conceito de vida em tempos de pandemia
}

The virus and the concept of life in times of pandemic

\section{Roberto Santos Ramos*}

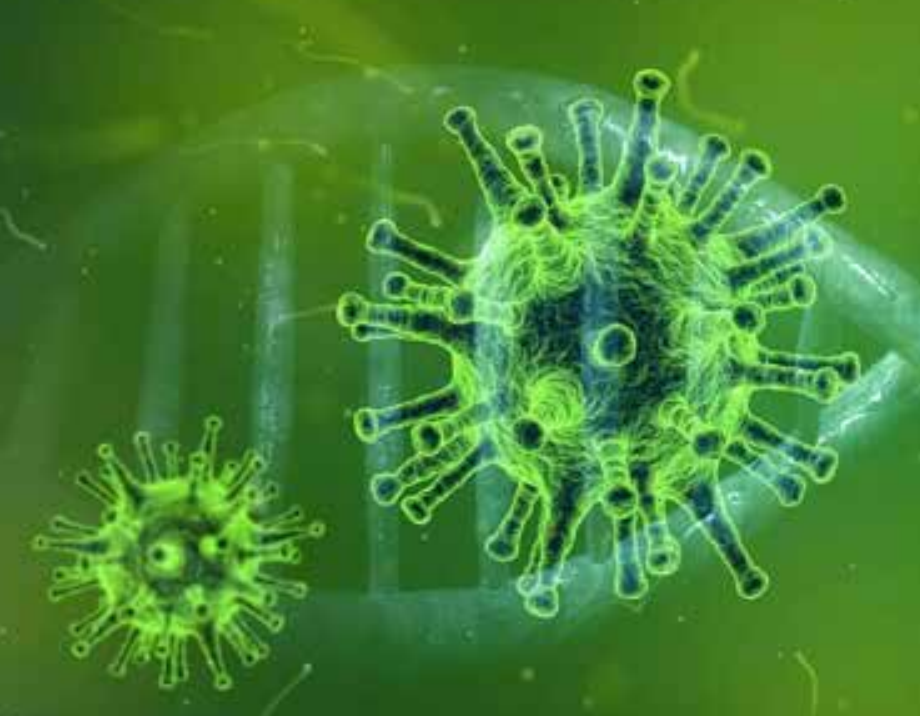




\section{RESUMO}

A pandemia da covid-ı9 (causada pelo vírus Sars-CoV-2) tem vitimado milhões de pessoas em todo o mundo, gerando discussões sobre vários aspectos. No âmbito da filosofia da biologia e na biologia, o debate sobre o conceito de vida sempre se colocou como desafio, uma vez que conceitos operacionais utilizados na biologia nem sempre deram conta de sua complexidade, sendo possível até então conceituar processos vitais, mas dificilmente a própria vida. O vírus, devido à sua constituição parasitária obrigatória, além de não se integrar à teoria celular, abre um leque de discussões por situar-se na fronteira vida/não vida. O vírus permanece inerte fora da célula hospedeira, mas atuante quando em relação de parasitismo, podendo levar seu hospedeiro à morte. $\mathrm{O}$ objetivo do presente artigo é discutir a noção de vida à luz da seleção de replicadores, visando analisar a informação genética como atributo universalizante dos organismos, e, a partir dessa discussão, contribuir por meio da análise filosófica para a formulação de um conceito de vida na biologia. Como resultado da presente análise, constatamos que o vírus não pode ser excluído do processo evolutivo natural, uma vez que compartilha informação genética, bem como sua origem por via do mundo do RNA, corroborando também a replicação da informação genética, comum no mundo vivo. Além disso, o vírus se organiza simbioticamente diante das propriedades intrínsecas e emergentes dos processos vitais, o que nos leva a concluir que os critérios operacionais não abarcam os vírus como seres vivos, ao passo que a seleção de replicadores, sim.

Palavras-chave: Pandemia. Vírus. Conceito de vida. Filosofia. Biologia.

\section{ABSTRACT}

The pandemic of covid-I9 (caused by the Sars-CoV-2 virus) has victimized millions of people worldwide, generating discussions on various aspects. In the scope of the philosophy of biology and in biology, the debate about the concept of life has always been a challenge, since the operational concepts used in biology have not always taken into account its complexity, being possible still today to conceptualize vital processes, but hardly life itself. The virus, due to its mandatory parasitic constitution, besides not being integrated into cell theory, opens a range of discussions because it is situated on the life/non-life frontier. The virus remains inert outside the host cell, but is active when in a parasitic relationship with the host, and can lead it to death. The aim of this article is to discuss the notion of life in the light of replicators selection, analyzing the genetic information as a universalizing attribute of organisms, and from this discussion, to enable, through philosophical analysis, contributions towards a concept of life in biology. We conclude virus cannot be excluded from natural evolutionary process, since it shares genetic information. We also should consider its origins coming from the RNA world, also corroborating the replication of genetic information, common in the living world. Moreover, the virus organizes itself symbiotically as against intrinsic and emerging properties of vital processes, which causes us to conclude the operational criteria does not embrace viruses as living beings, while the selection of replicators does.

Keywords: Pandemic. Viruses. Concept of life. Philosophy. Biology. 


\section{INTRODUCÃ̃o}

O surto pandêmico da covid-I9 (causada pelo novo coronavírus), declarado pela Organização Mundial da Saúde no dia II de março de 2020, abre um novo capítulo na história das epidemias e vem assolando de forma apavorante órgãos de saúde, equipes médicas, pesquisadores e principalmente os indivíduos mais vulneráveis à doença, quer seja por comorbidades, quer por situação social e econômica, que os expõe de forma amplificada aos riscos de contaminação. Essa epidemia iniciou-se em Wuhan, na China, em meados de 20I9, através de um fenômeno conhecido como "'transbordamento zoonótico', comum à maioria dos vírus, que fez com que um coronavírus que acomete morcegos sofresse uma mutação e passasse a infectar humanos" (FIOCRUZ, s.d.).

O coronavírus é um vírus com uma única fita simples de RNA, se espalha muito rapidamente e seus mecanismos de contaminação ocorrem por meio das vias respiratórias, canais de acesso ao corpo do possível hospedeiro, de cujo metabolismo se utiliza para replicar seu material genético. Como resultado dessa infecção, esse tipo de vírus - Sars-CoV-2 - causará a síndrome respiratória aguda grave — sars - , que vem ceifando a vida de centenas de milhares de pessoas em todo o mundo, principalmente por conta da baixa capacidade de suporte dos sistemas de saúde.

De acordo com a Universidade Johns Hopkins, até o dia 20 de julho de 2020, haviam sido infectados mais de 14 milhões de pessoas em todo o mundo, com fatalidades chegando a mais de 609 mil. Conforme essa mesma plataforma, até o dia 24 de março de 202I, o número de infectados passava dos 124 milhões, com quase 2,7milhões de vítimas fatais. No Brasil, terceiro país com maior número de contaminados, o número de vítimas fatais pulou de 80.I2o para 298.676 entre essas datas, sem considerar as subnotificações, que são proeminentes no país.

O impacto da pandemia de covid-I9 que vivenciamos suscita-nos reflexões, dentre elas, as voltadas ao ensino de biologia e ciências ao abordar os vírus, seres que não se encaixam no conceito de organismo vivo e que, consequentemente, levam-nos a refletir sobre a dificuldade em conceituar vida na biologia teórica.

O conceito de vida é tratado nos primeiros capítulos dos livros-textos trabalhados nas escolas, e, com isso, tanto as disciplinas de Ciências no ensino fundamental quanto a Biologia no ensino médio são organizadas, em grande parte, por conceitos biológicos cujos fundamentos devem ser apropriados nos processos de formação inicial e continuada. Assim, o conceito ou mesmo noção de vida analisada pelas ciências biológicas demanda conhecimentos acerca da teoria de conceitos e da forma como se refere aos objetos, processos, comportamentos e tudo que pode estar presente ou imaginado na nossa experiência de interações no espaço-tempo, cujos significados recebem denominações que são reproduzidas pelas diferentes sociedades.

Dessa forma, os conceitos exercem um papel muito importante para a formação de teorias, que no caso da biologia vêm da "descoberta de novos fatos (observação) e desenvolvimento de novos conceitos" (MAYR, 2008, p. 95), pois nos permitem 
abordar o mundo natural, com base em seu componente linguístico, como um intermediador entre o ser humano e os entes presentes ou representados no mundo físico. Diariamente interagimos com entes: coisas, pessoas, sentimentos, cuja compreensão está atrelada à nossa capacidade de lhes atribuir conceitos dando-lhes significado, ou seja, o ente abstrato do signo. Dahlberg (1978, p. I02), compreende a formação dos conceitos como a reunião e compilação de enunciados verdadeiros a respeito de determinado objeto. A conceituação dos objetos se vale da reunião de suas características, que por sua vez são descritas por enunciados.

Para Mayr (2008, p. 49),

conceitos como competição, origem comum, território e altruísmo são tão significativos na biologia quanto são as leis e descobertas nas ciências físicas, e assim mesmo sua importância foi estranhamente ignorada até bem recentemente. Essa negligência se reflete, por exemplo, nas categorias estabelecidas para o Prêmio Nobel. Mesmo se houvesse um Prêmio Nobel para a biologia (o que não é o caso), Darwin não poderia ter sido premiado pelo desenvolvimento do conceito de seleção natural - certamente o maior feito científico do século XIX — porque a seleção natural não foi uma descoberta. Essa atitude que favorece descobertas em detrimento de conceitos continua até os dias de hoje, mas em menor grau do que nos tempos de Darwin.

Considerando a importância dos conceitos usados nas ciências biológicas, a análise das características e enunciados do vírus e sua relação com a problemática do conceito de vida proporciona-nos uma aproximação desse debate, uma vez que o "fenômeno da vida mostra de fato muitos lados diferentes (que aparecem em vários níveis de organização), não sendo fácil capturar todos eles em um único esquema conceitual" (RUIZ-MIRAZO; PERETÓ; MORENO, 2004, p. 324).

Assim, os conceitos permitem abordar o mundo natural por meio do seu componente linguístico, como intermediador entre o ser humano e os entes presentes ou representados no mundo físico. Importante mencionar que essa intermediação não é neutra, ela leva em consideração os pressupostos, teses, hipóteses e teorias prévias presentes na investigação científica sobre o objeto empírico.

Em se tratando do nosso artigo, seu objeto, motivo da presente discussão, é o vírus que demonstrou sua importância na saúde coletiva diante da pandemia de covid-I9. Para a população humana de modo geral, os vírus são seres microscópicos patogênicos: normalmente ela não leva em consideração as relações de cunho ecológico desses organismos, numa perspectiva sistêmica que culmina na biosfera, como as simbioses presentes nas relações com muitos seres vivos, formando uma microbiota junto com outros microrganismos que se beneficiam mutuamente; além disso, eles contribuem na ciclagem de matéria orgânica e no "controle" numérico das populações com as quais se relacionam.

A etimologia da palavra vírus é o latim virus, que significa "veneno" ou "toxina". Do ponto de vista da virologia, são agentes infecciosos constituídos por um dos 


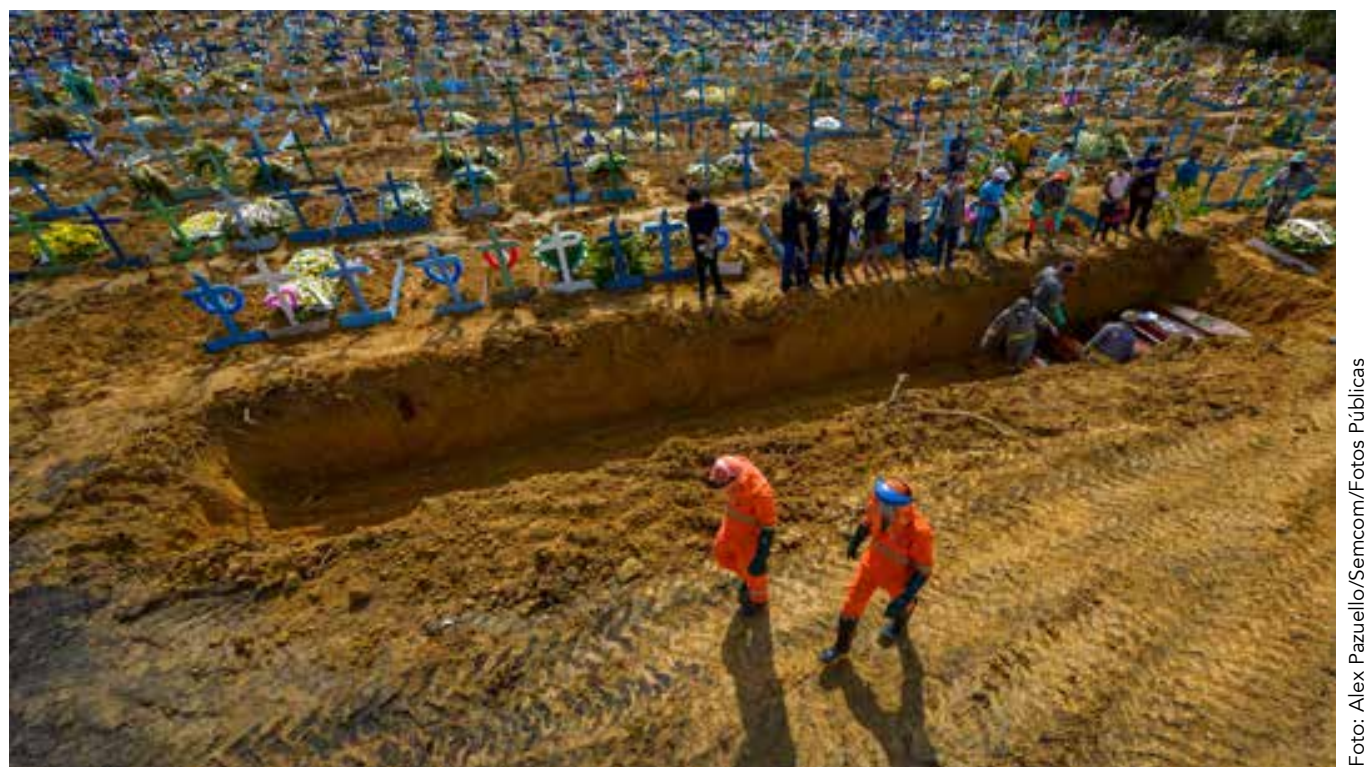

Cemitério público em Manaus: enterros coletivos para dar conta da "demanda"

ácidos nucleicos e envoltos por um capsídeo, composto de uma ou mais proteínas, que individualiza essas moléculas (DNA ou RNA) do ambiente, funcionando como proteção.

Para Campbell e Reece (20I0, p. 390), um vírus isolado é biologicamente inerte, incapaz de replicar seus genes ou regenerar o próprio suprimento de ATP. Assim, os vírus, por não serem constituídos por células, contrariam a teoria celular proposta por Matthias Schleiden (I804-I88I) e Theodor Schwann (I8IO-I882) que diz que todos os seres vivos são formados por células. No entanto, os impactos dos vírus se mostram aterradores, uma vez que, ao infectar seres vivos, e dentre eles os humanos, afetam drasticamente seu sistema imunológico, e, consequentemente, a homeostase ${ }^{\mathrm{I}}$ dos hospedeiros, podendo levá-los à morte, a um estado adverso à vida e suas formas complexas, biodiversas e resilientes, fruto de bilhões de anos de evolução.

A vida constitui-se de processos fisiológicos e estruturais universalizantes, tais como a replicação da informação genética, o metabolismo, a especificidade da constituição e processos físico-químicos como a presença de carbono e de estruturas moleculares e citoplasmáticas que fazem da célula a menor unidade morfofisiológica do ser vivo. Consideram-se ainda, nessa gama do que consideramos vida, os seus níveis de organização, que se distribuem em categorias que vão, conforme os biólogos, desde as moléculas orgânicas até a biosfera.

Essa resumida caracterização aponta para uma compreensão, ainda que superficial, do que se entende por vida na biologia, mas, ainda assim, tal conceituação,

"Condição fisiológica equilibrada do corpo" (CAMPBELL; REECE, 2010, p. 390). A homeostase referese ao equilíbrio dinâmico de processos internos que são controlados pela interação de mecanismos de integração, levando-se em consideração uma relativa estabilidade dentro de um intervalo aceitável de parâmetros para que as funções biológicas ocorram de forma a superar as contingências e condições adversas do meio. 


\section{A abordagem do}

vírus com base nos

aspectos operacionais,

ontológicos ou

epistemológicos ajuda-

nos a jogar luz sobre

os fundamentos do

edifício chamado vida

tanto na biologia quanto na filosofia da biologia, constitui-se em um grande desafio, uma vez que não há consenso entre pesquisadores, biólogos, físicos e filósofos sobre sua abrangência conceitual. A abordagem do vírus com base nos aspectos operacionais, ontológicos ou epistemológicos ajuda-nos a jogar luz sobre os fundamentos do edifício chamado vida e, por certo, deverá nos proporcionar uma ampliação das análises acerca desse tema tão desafiador, que extrapola salas de aula, laboratórios de pesquisa, experimentos, demandando enfim uma análise orientada pelos fundamentos e princípios da filosofia, bem como das contribuições das demais áreas de conhecimento relacionadas a essa temática.

\section{A VIDA COMO PONTO DE PARTIDA}

Qual o conceito de vida? Essa pergunta sempre ensejou a busca por respostas desde o homem comum até os cientistas e filósofos, principalmente os ligados às ciências naturais. A necessidade da compreensão desse conceito esteve presente em diferentes espaços, como também em larga escala temporal, desde os tempos mais antigos, quando alguns filósofos admitiam ser um fenômeno da enteléquia que anima a matéria, até os dias atuais, em que a exploração espacial, as tecnologias de informação e a manipulação de DNA são realidades que igualmente reacendem o debate sob novas vertentes, apoiado no vasto conhecimento gerado nos últimos milênios, para o qual as respostas ainda não se mostram satisfatórias. E, como afirma Oparin (1955, p. 7), "sem essa resposta, não poderia haver concepção de mundo, por mais primitiva que fosse. [...] Não há sistema filosófico ou pensador que não lhe tenha dedicado a mais séria atenção."

A divisão de um sistema vivo para um não vivo se torna difícil de delimitar, uma vez que os componentes estruturais de ambos, bem como a maioria das suas reações químicas e processos físicos, estão submetidos às mesmas leis físicas. Isso apon- 
ta para a necessidade de uma compreensão dinâmica, sinérgica e simbiótica desses componentes e seus processos. Margulis e Sagan (2002, p. 33) corroboram essa ideia quando citam que a natureza, conforme "Aristóteles, avança paulatinamente das coisas sem vida para a vida animal, de tal maneira que é impossível determinar a linha de demarcação exata". Acrescentamos: não só a vida animal, mas todo ser vivo, cuja abrangência exige concepções e métodos científicos próprios.

Dentre várias tentativas de estudiosos na busca por respostas ao que é vida, destacamos a obra, relativamente recente, do físico alemão Schrodinger (1997), O que é vida?..., na qual, cercado de métodos, instrumentos e concepções balizadas pela física, afirma que a vida se manifesta no mundo material e se submete às suas leis, e a resposta para o questionamento partiria do conhecimento dos menores componentes dos seres vivos. Alguns temas resgatados pelo autor para compor sua tese foram entropia, teoria quântica e movimento das moléculas, dentre outros, de modo a construir respostas ao questionamento indicado no título de sua obra, de forma a qualificá-la, ou até mesmo defini-la. Schrodinger (1997, p. 84), ao discutir a capacidade dos organismos vivos de atrasar o decaimento no equilíbrio termodinâmico (morte), assume que há uma organização mantida pela extração de "ordem" do ambiente, buscando assim diminuir a entropia gerada nos sistemas vivos através do metabolismo.

Entretanto, concepções dessa natureza estariam mais próximas do aspecto reducionista quando comparadas com as obras de Margulis e Sagan (2002) que corroboram Maturana e Varela (2003), criadores do conceito de autopoiese ${ }^{2}$. Esses autores se apoiam mais numa perspectiva holística do conceito de vida. Pois, mediante o estudo biológico dos organismos, mesmo com concepções das mais variadas, recaem em "descrições hesitantes [..., ficam aquém de qualquer definição derradeira da vida. Não proferiremos a última palavra, o julgamento final, porque a vida transcende a si mesma; qualquer definição nos escapa" (MARGULIS; SAGAN, 2002, p. 226). Nessa direção, Ruiz-Mirazo, Peretó e Moreno (2004, p.324) levantam perspectivas que vão desde as formulações pelos céticos quanto "à possibilidade real de apreender 'em qualquer linguagem cientificamente relevante' um fenômeno tão complexo e multifacetado" até as que indicam que, mesmo se fosse possível "obter uma definição adequada de vida, ela ainda seria bastante convencional".

A ideia de vida como organização perpassa diferentes épocas, uma vez que a estrutura de moléculas orgânicas, de alguma forma, se liga à sua significação ou finalidade. Não que necessariamente haja um aspecto teleológico operando, mas considera-se importante a complexidade e dinâmica dessas estruturas para lidar com as contingências que engendram o desempenho dos organismos vivos na luta pela vida.

\footnotetext{
Do grego auto ("próprio") e poiesis ("criação"). Entendida como a organização do ser vivo que se explica a si mesma ao ser vista como uma operação circular fechada de produção de componentes que produzem a própria rede de relações de componentes que os gera. Esse tipo de organização, entendida como sistema, se diferencia de outras organizações. Para Maturana e Varela (1995, p. 89), o que distingue a organização da vida de outras formas de organização "é ser tal que seu único produto são eles mesmos, inexistindo separação entre produtor e produto. $\bigcirc$ ser e o fazer de uma unidade autopoiética são inseparáveis, e esse constitui seu modo específico de organização".
} 


\section{Percebe-se então que a vida apresenta um princípio de reação às vicissitudes do meio, diante do qual faz de sua organização uma particularidade da matéria inanimada}

As proposições de novos conhecimentos a respeito da vida e possíveis conceitos corroboraram a corrente do fisicalismo ${ }^{3}$, que superou o vitalismo ${ }^{4}$ no século XVII, ao propugnar uma ontologia da vida baseada na ciência física, cujas leis regem a dinâmica dos objetos materiais do mundo, que são constituídos através de processos históricos. Logo, conforme Gould (I997, p. 47), não se pode responder à questão "O que é vida?" sem compreender os acontecimentos do passado.

Quando da formação das primeiras moléculas na sopa primordial, há 3,6 bilhões de anos, uma membrana que isolava determinado conteúdo do ambiente externo criou condições diferenciadas que relacionavam fenômenos físicos, químicos e biológicos e conferiam a essa estrutura recém-criada algum tipo de capacidade, tal qual cada ser, conforme Goethe (I837 apud JACOB, I983, p. 96), contém em si mesmo a razão de sua existência, ou seja, um produto organizado na natureza se mostra como meio e fim em si mesmo. Ainda para Jacob (1983, p. 96), "é o conjunto da estrutura que funda a possibilidade de sua coesão, que representa a ordem no meio da desordem". Com isso, forças internas geradas nessas estruturas criam condições que "buscam" impedir a ruína, ou mesmo a ocorrência do acaso.

Percebe-se então que a vida apresenta um princípio de reação às vicissitudes do meio, diante do qual faz de sua organização uma particularidade da matéria inanimada. Por conseguinte, a conceituação de vida em épocas anteriores guarda estreita relação com as raízes desse princípio. Jacob (1983, p. 97) relaciona alguns estudiosos com suas respectivas definições ou entendimentos de vida, como Bichat, que diz que a vida

\footnotetext{
Podemos entender fisicalismo como uma tese metafísica que enuncia que as diversas áreas do conhecimento devem elevar a física à condição de um paradigma científico universal segundo o qual "tudo que 'existe' ou tudo o que é 'real' no mundo espaço-temporal é um 'fato físico' ou uma 'entidade física', em que as 'propriedades' dos fatos físicos ou são propriedades físicas em si ou são propriedades 'constituídas/realizadas/compostas' por propriedades físicas" (ZILIO, 2010, p. 219). Papineau (2000, p. 178) defende o fisicalismo apoiando-se num argumento empírico crucial: os efeitos físicos são devidos a causas físicas, e portanto essas causas, por gerarem efeitos físicos, devem ser elas mesmas físicas. Para Stoljar (2019, p. 1), a ideia do fisicalismo está associada à natureza do mundo real (ou seja, o Universo e tudo que nele existe), tendo como condição necessária que essa existência seja de ordem física, erigida por leis mecânicas que atuam sobre a matéria, incapaz de se auto-organizar espontaneamente.

4 O pensamento vitalista fundamenta-se em várias religiões, supondo que um ser supremo teria insuflado uma força invisível na carne inanimada e inerte, e que essa parcela da divindade do mundo é o vivo, o que move o ser e o mantém com vida. Ou seja, a vida é uma manifestação da divindade, uma força vital ou oculta, sem a qual a vida não poderia ser explicada, e quando ela se esvaece, só permanece o invólucro material vazio. Oparin $(1955$, p. 8) utiliza o termo idealismo para se referir a essa corrente que considera a vida como manifestação de um princípio espiritual superior e imaterial. A matéria é inerte e tomada por essa parcela eterna da divindade que a faz mover-se e manter-se com vida.
} 
é o conjunto das funções que se opõem à morte; para Cuvier, é a força que resiste às leis que governam os corpos brutos; para Goethe, é a força produtora contra a ação dos elementos exteriores; para Liebig, a força motriz que neutraliza as forças químicas, é a coesão e a afinidade que agem entre as moléculas.

Nessa perspectiva, a concepção da morte como oposição à vida, ou sua negação, complementa-se com outro viés de entendimento e significado. Assim, a morte, como Jacob (1983, p. 98) afirma, se configura como a derrota desse princípio de resistência que gera como produto um corpo submetido novamente ao domínio das forças físicas. O elemento biológico já não se mostra presente. A potência da entidade para se auto-organizar e seguir seus processos contra a entropia natural da matéria inexiste, restando apenas um corpo em decomposição, um corpo sem vida. Entretanto, numa perspectiva ecossistêmica, esse corpo "vazio" tornar-se-ia a matéria-prima para a reconstrução da própria vida.

Destarte, a vida, para Weber (2015, p. I6), se autodeterminaria e se autossustentaria como entidade autocatalítica de transdução de energia, na qual as informações genéticas são repassadas de geração a geração por meio dos ácidos nucleicos que se replicam no contexto de células e trabalham com outros recursos de desenvolvimento durante os ciclos de vida dos organismos.

Com efeito, os questionamentos que buscam diferenciar vida de não vida partem de princípios e concepções acerca da natureza do conhecimento, com seus postulados e métodos, cujos critérios acordados pela comunidade científica e filósofos da ciência ajudam-nos a jogar luz sobre um tema tão instigante e desafiador. Ademais, a discussão sobre o "lugar" do vírus na organização da vida parece reunir de forma objetiva os elementos dessa problemática no processo da análise filosófica.

\section{A BIOLOGIA E A NATUREZA DO ESTUDO DA VIDA}

O termo biologia foi cunhado com maior precisão no início do século XIX por Lamarck e Gottfried Treviranus, como área do conhecimento voltada ao estudo da vida. Menezes (1986, p. 63), entretanto, nos aponta em seu trabalho a divergência de denominação desde a época de Aristóteles, filósofo da Grécia antiga que já se referia à zoologia através de sua obra Historia animalium. E, com sua vasta produção filosófica, Aristóteles dividiu a ciência da época, conforme afirmam Sedwick e Tyler (p. 75 apud MENEZES, I986, p. 63) em três grupos: a teórica, a prática e a criativa, sendo que o primeiro grupo compreendia a metafísica, matemática e física, esta última incluía entre os seus objetos tanto corpos animados quanto inanimados. A biologia do filósofo estagirita foi pioneira no estudo de comportamentos animais e no emprego da dissecação com o objetivo de observar e relatar (LLOYD, I968).

O período entre os séculos XVIII e XX registrou marcos temporais de muitas transformações, culminando nas áreas da cultura, filosofia, política, economia e 
principalmente na ciência que se fragmentou em áreas mais especializadas, tendo na física o modelo para estabelecer problemas filosóficos fundamentais como comuns a todas as demais ciências, tendência essa conhecida como reducionismo 5 , que acabaria por se tornar um problema futuro para a autonomia da biologia, uma vez que muitas concepções filosóficas e científicas calcadas no reducionismo se embasavam no empirismo lógico proveniente do Círculo de Viena ${ }^{6}$.

A biologia elevou-se ao status de disciplina autônoma após intensas discussões entre cientistas e estudiosos sobre o reducionismo não só entre as ciências, mas também no interior delas, como na questão da submissão de processos biológicos às leis da física. Nessa perspectiva, Mayr (2005, p. 329) aponta outros dois conjuntos de eventos que contribuíram para o reconhecimento da biologia: a refutação de certos princípios equivocados, como o vitalismo e a crença na teleologia cósmica; e a percepção do caráter único de certos princípios básicos da biologia que não são aplicáveis ao mundo inanimado.

Dessa forma, a biologia desdobra-se nos estudos, pesquisas e concepções acerca dos seres vivos e, por conseguinte, da vida que se manifesta em uma gama de processos e mecanismos, mobilizando algumas classificações importantes, como as que Mayr (2005, p. 377) propõe: biologia funcional, que lida com a fisiologia de todas as atividades de organismos vivos; e a biologia histórica, que se mostra indispensável para a explicação dos aspectos do mundo vivo que envolvem a dimensão de tempo histórico.

Por certo, a biologia ocupa um lugar importante na compreensão do mundo natural. Tal lugar, conforme Monod (I97I, p. 9), é ao mesmo tempo marginal e central, uma vez que o mundo vivo constitui parte ínfima do Universo conhecido, e seu estudo parece não revelar leis gerais, aplicáveis fora da biosfera?

\footnotetext{
"Esse tema sempre foi caro aos filósofos da ciência e diz respeito à possibilidade de se reduzirem descrições em um nível (propostas por uma ciência) a descrições em outro nível, que se considere ontologicamente mais básico ou fundamental (propostas por aquela mesma ciência ou por alguma outra)." (ABRANTES, 2018, p. 3)

6 O Círculo de Viena (Wiener Kreis, em alemão; Circolo di Vienna, em italiano) foi um grupo de filósofos que compreendia, entre outros, Kurt Gödel, Philipp Frank, Frieadrich Waissmann, Otto Neurath, Rudolf Carnap e o professor Moritz Schlick, da Universidade de Viena. Esses filósofos frequentaram a Universidade de Viena entre os anos de 1922 e 1936, publicaram um manifesto em 1929 com o título "Wissenschaftliche Weltauffassung" ("concepção científica de mundo", em tradução nossa), sabidamente redigido por Neurath, Carnap e Hans Hahn. Esse manifesto tinha como objetivo maior refletir sobre como a ciência chega ao conhecimento do mundo, examinando para isso os fundamentos e os métodos da ciência. No primeiro tópico, são resgatados os antecedentes históricos, citando aspectos que confrontam o pensamento metafísico. No segundo tópico, intitulado "Concepção científica de mundo", são tratados os aspectos dos diferentes conhecimentos, tendo, porém, o objetivo de uma ciência unificada. Um dos principais objetivos do Círculo de Viena era dar conta da objetividade e inteligibilidade do método e dos conceitos científicos, além de constatar a superação da metafísica, reconstruindo inclusive a própria filosofia sob essas novas bases teóricas. Dentre os movimentos correntes influenciados pelo Círculo de Viena, estão: liberalismo, tradição empirista britânica, iluminismo e utilitarismo.

Percebe-se um movimento para integrar uma gama de leis, processos e mecanismos, fomentados de certa forma pelo positivismo lógico, numa teoria que busque unificar ou explicar toda a natureza com base num só mecanismo, ou mesmo numa visão que tenha por base uma ciência unificada. Tal movimento se mostra um tanto pretensioso, com riscos de almejar adequar a realidade intrínseca da natureza às concepções humanas em suas relações com o mundo.
} 
Mas, se a ambição última de toda ciência é, como penso, a de elucidar a relação homem com o Universo, então devemos reconhecer à biologia um lugar central, pois ela é, entre todas as disciplinas, a que tenta penetrar mais diretamente no cerne dos problemas que devem ser resolvidos antes mesmo que possa ser colocado o da natureza em termos diferentes dos da metafísica (MONOD, I97I, p. 9).

Na virada do século XVIII para o século XIX, o conceito de vida, conforme Corrêa (2008, p. 22), constituiu-se em um problema de cunho científico, momento em que a disciplina de biologia já estava formada, e explicar vida passou a ser um problema, pois até então o que existia eram os estudos sobre os seres vivos, considerados como categorias taxonômicas das coisas naturais, cujos processos eram explicados com base no fisicalismo ${ }^{8}$. Destarte, já no século XX, Mayr (2005) vê na biologia a possibilidade de estudo dos seres vivos como composição da matéria inanimada, sendo possível apenas definir seus processos de vida, mas não o conceito.

A estrutura e a função estão interligadas nos processos naturais, conferindo homeostase a cada nível de organização da vida, além de permitirem por meio de sua relação uma otimização e capacidade de reação ligadas à assimilação de energia e substâncias e sua consequente redistribuição para diferentes partes do corpo dos seres vivos.Um exemplo nessa direção diz respeito à célula, na qual a razão entre volume e área de superfície confere estabilidade biológica à troca de matéria e energia com o meio exterior. Dessa forma se explica o fato de indivíduos de grande porte possuírem células pequenas, como forma de manter uma razão eficiente entre área e volume celular, ampliando sua capacidade de desempenhar funções diferentes e necessárias para a sobrevivência dos organismos.

As células tornaram-se então as unidades estruturais básicas morfofisiológicas de todo ser vivo, consideradas, em seu conjunto, blocos construtores da vida. Com isso, a teoria celular proposta por Theodor Schwann e Mathias Schleiden, em I838, confere um princípio unificador à biologia, cujas premissas, de acordo com Sadava et al. (2009, p. 5), são três: I) células são as unidades distintas e fundamentais da vida; 2) todos os organismos são compostos por células; 3) todas as células originam-se de células preexistentes.

Importante lembrar que essa unidade fundamental da vida só corresponde às premissas da teoria celular porque carrega em seu interior ácidos nucleicos capazes de replicação e que, em ação conjunta com a evolução, de acordo com Nunes e Oliveira (2000, p. I39), garantem aos sistemas vivos o sucesso na tarefa de autoperpetuação, não bastando apenas que organismos criem cópias de si mesmos, mas que sejam também aptos a criar novas versões capazes de se adaptar a situações adversas

\footnotetext{
El-Hani (2000, p. 60), baseado nos trabalhos de Levine e colaboradores, esboça bem em seu trabalho os tipos de fisicalismo, dentre os quais adotamos, mesmo com as críticas de Kim, o fisicalismo não redutivo, uma posição filosófica que considera que as macropropriedades constituem um domínio autônomo de propriedades irredutíveis. Esse tipo de fisicalismo visa estabelecer uma relação de determinação e dependência sem redução entre conjuntos de propriedades.
} 
do meio. Nunes e Oliveira (2000, p. 139) concordam com Weber (2015, p. 2) quanto aos fenômenos evolutivos, justamente por assumir que estes apresentam um aspecto inextricável dos sistemas vivos, cujo mecanismo jamais pode ser dissociado de outra característica inerente ao conceito de vida, e, com isso, qualquer tentativa de definir a vida na ausência dessa perspectiva diacrônica será fútil.

Na visão de Richard Dawkins ${ }^{9}$, o material celular, assim como os mecanismos comportamentais e arranjos fisiológicos e estruturais nos vários níveis de organização da vida, se arranjam para proteger e transportar a informação genética, a base molecular da construção do ser vivo em forma de código, com possibilidade de uma grande variação dos tipos naturais. Ainda nessa direção, para ele, os corpos seriam máquinas criadas pelos genes que podem atingir mais efetivamente seus próprios objetivos egoístas, cultivando uma forma limitada de altruísmo. Dawkins (2007), ao defender sua tese, aponta uma maneira de olhar para a evolução considerando que esta se dá no mais baixo de todos os níveis, ou seja, em um gene, em um trecho do DNA que guarda informações acerca da hereditariedade de cada ser vivo, considerado como unidade fundamental da seleção.

Monod (I97I, p. Io) concorda que a teoria do código genético, numa acepção ampla da expressão morfogenética e fisiológica dos mecanismos moleculares, se constitui na base fundamental da biologia. Dessa forma, esquematizam-se as espécies viventes e já extintas numa árvore filogenética de compartilhamento da informação genética, fruto de bilhões de anos de evolução. Essa unidade sobre a qual assenta a história da vida inicia-se entre 3 a 4 bilhões de anos atrás, em meio a aglomerados moleculares estáveis, e dentre esses, alguns surgem com a capacidade de criar cópias de si mesmos, como o RNA ou um percussor, conforme Eigen (I997, p. 23), capaz de assumir a capacidade de armazenamento de informação autorreplicável, necessário para pôr o carrossel da evolução em movimento. Esses constituintes químicos, guardiões da informação genética, se configuraram como os mais remotos da gama de seres vivos. Já o DNA passou a ser o invariante biológico fundamental, e a elucidação de sua estrutura mudou completamente a pesquisa biológica.

Tais afirmações têm respaldo no vasto conhecimento e nas descobertas que se consolidaram nas ciências através dos tempos. É preciso, contudo, considerar que, no processo de evolução da ciência, muitos de seus fundamentos foram conformados de acordo com a visão de mundo, as descobertas e o contexto das diferentes épocas. Como resultado desse processo dinâmico, a biologia no século XVIII, conforme Jacob (1983, p. 122), via na organização dos seres vivos propriedades que caracterizavam um organismo, como a soma das propriedades de cada molécula constituinte. Já no século XIX, essa visão muda vertiginosamente, para assumir que essas moléculas são elementos vivos e que não estão apenas reunidos, mas integrados.

Etólogo, biólogo evolutivo e escritor britânico, um dos principais divulgadores da ciência, defensor da teoria da evolução de Charles Darwin e grande crítico do criacionismo. Foi professor das universidades da Califórnia e de Oxford. Nasceu em Nairóbi (Quênia) em 1941. 
As unidades devem amalgamar-se em uma outra unidade de ordem superior. É necessário que se submetam ao organismo, que abdiquem de toda individualidade diante da individualidade do todo. Só assim o ser indivisível pode se compor de unidades elementares. O organismo não é uma coletividade, mas um monólito (JACOB, I983, p. I22).

Assim, a visão de célula advinda do século XVII, que acumulou informações sobre composição e reprodução dos animais e plantas, muda ao admitir as relações entre um ser vivo e seus componentes de forma integrada, esboçando a noção de que seja a célula o primeiro nível de organização da vida. Com isso, resolvem-se dois problemas aparentemente distintos, expostos por Maupertuis (I768) e Buffon (I979) apud Jacob (1983, p. I23), sobre a dissociação entre o estudo da reprodução dos seres vivos e o estudo de sua constituição, em que a decomposição dos seres em células, cada uma delas dotada de todas as propriedades do ser vivo, dá à reprodução ao mesmo tempo um significado e um mecanismo.

A busca por uma unidade fundamental da organização da vida parece se alinhar a uma espécie de "ambição platônica na pesquisa sistemática dos invariantes anatômicos" (MONOD, I97I, p. II9). Por esse ângulo, era perceptível uma variedade morfológica, bem como dos diferentes modos de vida. Ainda assim, diante dessa variabilidade, reconhecer certo padrão anatômico comum a certos grupos animais demonstrava uma natureza investigativa bem madura por parte dos estudiosos no século XIX. Isso posto, as afinidades dos diferentes grupos do reino Animalia seguia o pensamento da invariância, que classificava, por exemplo, conforme Monod (I97I, p. II9), os tunicados no grupo dos vertebrados, que encontrava afinidades entre cordados e equinodermos, além de relações filogenéticas entre ouriços e seres humanos muito mais próximas do que entre estes e os cefalópodes.

Com o advento da bioquímica e a ascendente biologia molecular, a categoria da invariância desce mais ainda na escala da complexa organização do mundo vivo, buscando essa unidade do ser vivo no nível das moléculas orgânicas que se organizam para formar blocos construtores da vida. Com essa base molecular, tanto em estrutura quanto em funcionamento, expressa nos diferentes organismos, os processos químicos são essencialmente os mesmos. Monod (I97I, p. I20) aponta como estrutura os invariantes bioquímicos, em que todos os organismos são constituídos pelas mesmas duas classes principais de macromoléculas, que são: proteínas e seus aminoácidos, em número finito de 20 , e ácidos nucleicos, constituídos também em número finito de quatro nucleotídeos. Os nucleotídeos arranjados formam o DNA, configurando-se este como o invariante fundamental da vida, sendo que a sequência dessas moléculas especifica um gene, uma unidade hereditária que codificará determinado fenótipo do ser vivo.

Já em termos de funcionamento, consoante Monod (I97I, p. I20), ocorrem as mesmas sequências de reações químicas utilizadas em todos os organismos para as operações químicas essenciais, tais como mobilização e reserva de potencial químico 


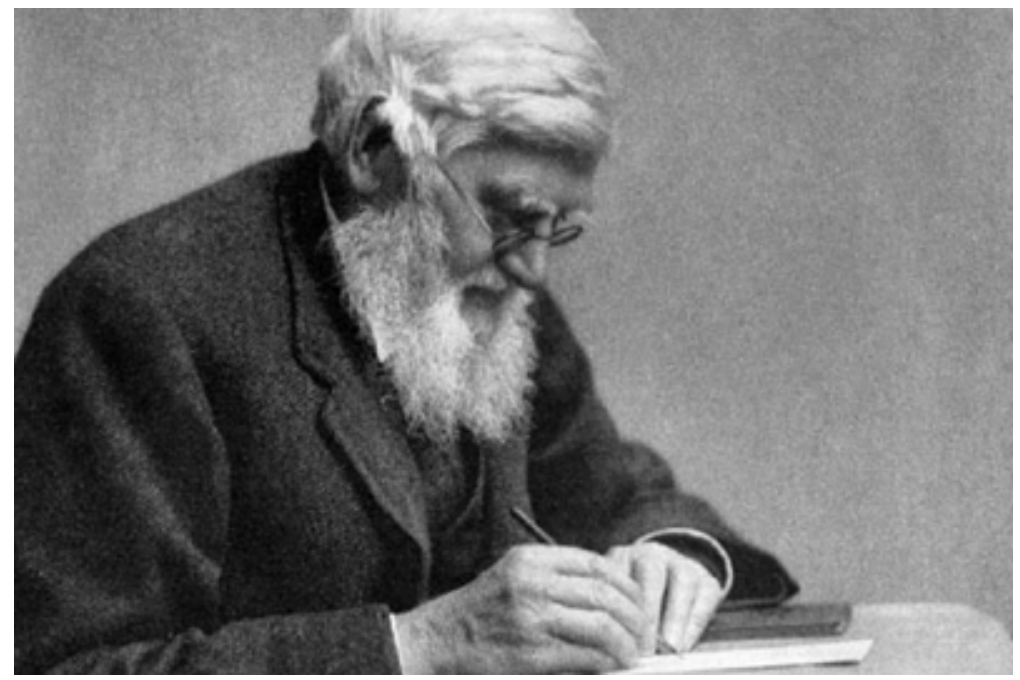

O biólogo britânico

Charles Darwin

(1809-1882)

e biossíntese dos constituintes celulares. Esse complexo de vias metabólicas e suas reações químicas é processado segundo os mesmos mecanismos físico-químicos nos seres vivos, configurando o metabolismo desses organismos com capacidade de síntese e desassimilação de compostos, com obtenção, transformação e armazenamento de energia para as atividades biológicas. Aliás, a transformação de energia, muito presente nos organismos, configura-se como uma característica com especificidades próprias, não ocorrendo no mundo não vivo.

A estrutura e o funcionamento do mundo vivo sempre direcionaram as pesquisas sobre processos nos organismos. Importante lembrar que no século passado, de acordo com Jacob (1983, p. II9), os tecidos, em sua composição para formar órgãos, vinham sendo estudados primeiramente em decorrência do plano de organização dos animais, tendo como estrutura elementar a fibra. Assim, esse componente elementar dos corpos vivos era a última etapa da análise anatômica, e dissecar um animal com o fim de entender sua organização pautava-se pela análise dos órgãos em função do seu papel fisiológico na totalidade do organismo. No entanto, em concordância com Cuvier (I835, p. xvii apud JACOB, I983, p. I07), diante das analogias, "as máquinas que constituem o objeto de nossas pesquisas não podem ser desmontadas sem ser destruídas", ou seja, separar partes de um todo orgânico e funcional em sua totalidade para estudá-las significaria desnaturalizá-las. Individualizar quaisquer dessas partes seria pôr um foco errôneo na compreensão do todo, uma vez que o objeto de estudo dissecado está desconectado de seus processos físico-químicos, biológico-históricos, indiferentes à própria fisiologia que lhe é necessária para a realização dos processos vitais.

Nesse sentido, a ideia de unidade elementar numa concepção de integração do corpo vivo impõe à caracterização da célula uma condição de individualidade, em que ela não transcende o conjunto, ou seja, ela não conserva sua individualidade num todo orgânico e complexo, antes se integra a outras células e demais estruturas e processos numa totalidade. Para Jacob (1983, p. I24), essa individualidade detém todas as propriedades e, ao mesmo tempo, o ponto de partida de todo o organismo. Porém, 
essa noção se configura reducionista, na medida em que "um fenômeno tinha de ser reduzido aos seus menores componentes para que se alcançasse sua completa explicação" (MAYR, 2005, p. I45), tema bastante discutido por filósofos da biologia, que se soma à problemática das propriedades emergentes. De acordo com Mayr (2008, p. 4I), esse termo designa o surgimento de novas propriedades em níveis superiores de organização e integração, que não poderiam ser previstas pelo conhecimento dos componentes em níveis inferiores. Essas questões têm sido negligenciadas pelos reducionistas. Ainda assim, Jacob (1983, p. 124) não vê tanta importância em que todos os organismos sejam constituídos por células, mas em que a célula possua todos os atributos do ser vivo, sendo ainda a origem necessária para todo corpo organizado.

Diante do exposto, os vírus, conforme sua estrutura e função, não se enquadram nas premissas da teoria celular consoante as quais todo ser vivo tem como unidade fundamental a célula. Além disso, sua definição como seres vivos se mostra num campo obscuro da fronteira entre vida e não vida, já que, por intermédio das condições suficientes e necessárias, essas entidades agem como seres vivos. Essa teoria se encontra bem cristalizada na biologia, proporcionada, dentre outros eventos, pela superação do vitalismo pelo fisicalismo, o que contribuiu na demarcação de um campo bem delimitado e fundamentado dessa área do conhecimento.

Contudo, problematizar o "local" do vírus na organização da vida sem deslegitimar tal teoria pode proporcionar uma profundidade no debate sobre o conceito de vida, tendo nos vírus uma entidade cuja existência não é possível negar, e sua abordagem coloca-se como provocativa, uma vez que essas entidades, como aponta Hartman (2000, p. 234), poderiam ter desempenhado um papel importante na evolução dos seres vivos, sendo esse o caminho ideal para examinar a natureza do vírus, na medida em que eles são situados pelas ciências biológicas na fronteira entre o mundo vivo e não vivo.

\section{OS VÍRUS NA FRONTEIRA DA VIDA}

Os vírus despertam uma reflexão que há muito tempo vem influindo nas definições do conceito de vida utilizado pelos biólogos, uma vez que os critérios operacionais que discernem a matéria viva da não viva não contemplam esses "organismos" facilmente na categoria do mundo vivo, haja vista que a base da organização dos sistemas vivos é pautada por um complexo aglomerado de substâncias orgânicas e estruturas que formam as células, consideradas blocos de construção da vida ou o primeiro nível de organização dos sistemas vivos. Sendo assim, os vírus não apresentam organização celular, mas, quando parasitam células hospedeiras, metabolizam-se, reproduzem-se, evoluem, reduzem temporariamente sua entropia, utilizam-se de toda a "maquinaria" celular e se comportam conforme a noção clássica de desempenho dos seres vivos, e assim correspondem aos critérios operacionais comumente utilizados nos sistemas de classificação da biologia, mesmo atuando numa relação de parasitismo obrigatório. 
Portanto, a definição de vida torna-se complexa quando nos atemos a critérios que nem sempre dão conta de abarcar as nuances de entidades que guardam em si a potência para exercer um mínimo de funções biológicas que seja considerado um processo da vida, como a reprodução. No caso dos vírus, a própria infecção viral com capacidade de interferência em outros organismos causa doenças diversas, podendo levá-los à morte. Por isso, conforme Campbell e Reece (20IO, p. 38I), os pesquisadores no final do século XVIII, ao fazer um paralelo com as bactérias, propuseram que os vírus fossem considerados as formas de vida mais simples.

Os vírus são parasitas intracelulares obrigatórios de diversos organismos dos grupos das plantas, animais, protistas, fungos e bactérias. Ao infectar células, utilizam-se do metabolismo de síntese das células para estabelecer os mecanismos moleculares que permitem replicar, transcrever e traduzir seu material genético (informação, em forma de partícula viral). Em sua maioria, causam doenças com ampla capacidade de se espalhar rapidamente no corpo dos organismos infectados. Quando estão fora das células hospedeiras, os vírus não se multiplicam e não apresentam nenhum tipo de atividade metabólica; nesses ambientes ficam restritos às estruturas microscópicas com material genético (DNA ou RNA, mas nunca os dois) envolto pelo capsídeo. Ao existirem como partículas fora da célula hospedeira, os vírus passam a ser chamados de vírions, os quais permaneceriam inertes.

$\mathrm{Na}$ visão de Hartman (2000, p. 234), a compreensão dos vírus como apenas causadores de doenças seria modificada num contexto ecológico e evolutivo mais amplo, no qual passam a desempenhar um papel importante na troca de material genético entre células por meio de infecção, possibilitando a troca de genes ou mesmo uma barreira genética, o que favorece a diversidade biológica entre organismos.

Os vírus são o produto de uma rede complexa de diferentes forças evolutivas. Eles prosperam mantendo uma interação contínua com os seus hospedeiros e estão sujeitos a uma multiplicidade de forças seletivas e mudanças estocásticas. A rápida produção de diversidade genética é uma característica exclusiva de certas linhagens virais, tem notáveis consequências epidemiológicas, e confere grande valor sobre vírus como sistemas modelo para a compreensão do processo evolutivo (BRANDÃO, 20I5, p. i).

Por serem acelulares, os vírus não seguem os níveis de organização da vida largamente conhecidos e difundidos na biologia, como os que se iniciam pela célula, desta para os tecidos que são formados por células e assim por diante, até a biosfera. Além disso, "não regulam o transporte de substâncias para dentro ou fora por meio de membranas, e não realizam funções metabólicas" (SADAVA et al., 2009, p. 283), isso quando não estão parasitando uma célula viva, pela qual podem se reproduzir nesses sistemas biológicos que desempenham tais funções.

Embora o conhecimento sobre os vírus tenha se evidenciado na última metade do século XX, sua descoberta se deu através das pesquisas, complementares, embora realizadas em épocas diferentes, de três principais cientistas: o matemático 
alemão Adolf Mayer em I883, o botânico russo Dmitri Ivanovsky em I892 e o microbiologista holandês Martinus Beijerinck em I989 (CAMPBELL; REECE, 20IO, p. 38I; SADAVA et al., 2009, p. 283).

Adolf Mayer descreveu pela primeira vez a doença do mosaico do tabaco e descobriu que poderia transmiti-la de planta para planta, esfregando a seiva extraída de uma folha doente em uma planta sadia. Sem êxito na identificação do agente etiológico, Mayer sugeriu ser uma bactéria pouco comum e invisível ao microscópio. Uma década depois, Ivanovsky testou tal hipótese ao filtrar um extrato de folhas doentes por um filtro de porcelana, técnica utilizada à época para isolar bactérias causadoras de doenças, resultando então numa seiva que ainda produzia a doença, ou seja, o filtro não reteria o agente causador, resultado que atribuiu ao tamanho da "bactéria" ou a uma suposta produção de toxinas que a ajudaria a passar pelo filtro. Beijerinck, por sua vez, repetiu os experimentos de Ivanovsky, descartando a segunda hipótese por meio de uma série de experimentos clássicos que mostraram que o agente infeccioso podia se reproduzir apenas em hospedeiro e difundia-se em ágar-gel, denominando o pequeno agente de contagium vivum fluidum.

Quase 40 anos após, o agente da doença foi cristalizado por Wendell Stanley, passando a ser conhecido por TMV - tobacco mosaic virus - e agora visto como infeccioso quando dissolvido. Foi demonstrado à época que as preparações virais cristalizadas consistiam em proteínas e ácidos nucleicos.

Estudos detalhados do mecanismo de infecção ocasionado pelos vírus "têm levado ao desenvolvimento de técnicas que permitem aos cientistas manipular os genes e transferi-los de um organismo para o outro", segundo Campbell e Reece (20I0, p. 38I). Para esses autores, essas técnicas desempenham um papel importante na pesquisa básica, na biotecnologia e em aplicações diversas na medicina, como na terapia gênica. É importante salientar que outras funções desempenhadas por meio dessas manipulações não atribuem necessariamente ao vírus um rótulo de agente unicamente causador de patologias e, por isso, dotado de capacidade deletéria por sua natureza parasitária e infecciosa.

Não obstante, dada a capacidade de integração dos organismos num sistema amplo e complexo que envolve o entorno, não se pode negligenciar a imunidade que alguns seres vivos complexos desenvolveram ao longo de milhares de anos, produzindo uma resposta imunológica capaz de reconhecer antígenos e inoculá-los para manter, com base na resiliência, a estrutura corporal e os processos metabólicos funcionais do hospedeiro. Certamente, tal sistema imunológico se mostra uma vantagem evolutiva importante em alguns grupos, possibilitando a ampliação das condições de perpetuação das espécies que o desenvolveram. Esses mecanismos de defesa são inatos e surgiram no decurso evolutivo das espécies, com mecanismos simplificados de reconhecimento dos antígenos, como a fagocitose dos protistas unicelulares, até sistemas vivos mais avançados na escala evolutiva, o que mostra essa funcionalidade bem aparente nos macrófagos dos vertebrados. 
Em virtude das vacinas, amplamente estudadas com foco nas populações humanas, possibilitou-se uma maior resistência a doenças provocadas por vírus e a cura delas, induzindo o corpo dos seres humanos a produzir anticorpos contra os patógenos que deflagram a resposta imunológica. Tais relações trazem à tona uma reflexão sobre a intervenção humana nos ciclos naturais de muitas espécies, como os vírus, objetivando auferir benefícios e podendo constituir estratégias "artificiais" que visem prolongar a vida dos humanos, bem como sua saúde. Não obstante, os custos decorrentes dessas intervenções também são notórios, como os que ora presenciamos por conta da pandemia de covid-I9.

Por muito tempo os vírus foram considerados formas de vida simples ou rudimentares, porém, esses agentes, diante dos métodos e conceitos adotados pela biologia e pelas ciências de modo geral, passaram a representar uma fronteira nebulosa entre a matéria viva e não viva, dada, dentre outros aspectos, a sua capacidade de induzir respostas imunológicas em vários táxons, entre os quais se inserem os humanos.

Sobre a origem dos vírus, embora não haja consenso sobre as hipóteses levantadas, verifica-se que está diretamente ligada à origem da vida. Nessa direção, ao analisar a origem da vida, observa-se que as etapas posteriores ao mundo pré-biótico seriam

o mundo do pré-RNA (onde se postula aparecerem as primeiras moléculas autorreplicantes) e o "mundo do RNA", após o surgimento de sistemas catalíticos e autorreplicantes com propriedades comparáveis às do ácido ribonucleico (RNA) contemporâneo (VIEYRA; SOUZA-BARROS, 200o, p. 77).

Denomina-se mundo do RNA uma fase hipotética primordial da vida na qual o RNA seria a molécula da hereditariedade. Para Hartman (2000, p. 239), as moléculas de RNA replicativas tinham a capacidade catalítica de polimerizar ${ }^{\text {Io }}$ RNA por meio de nucleotídeos ativados; com isso, elas seriam consideradas as primeiras entidades vivas. Essas entidades precederiam, então, o DNA. Essa visão parte de fundamentos encontrados na própria taxa de mutação do RNA, que seria deletéria, inviabilizaria a vida, como aponta Ridley (2007, p. 552) ao concluir que a mudança de RNA para DNA seria motivada por uma taxa de mutação relativamente alta de RNA, superior a 1, a qual não poderia sustentar futuras formas de vida assexuadas.

Os vírus de RNA atuais, como o HIV, têm taxas de mutação de cerca de IO4 por nucleotídeo. Isso limita sua capacidade codificadora a cerca de IO4 nucleotídeos, ou cerca de io genes. Formas de vida mais complexas não poderiam evoluir antes que a taxa de mutação se reduzisse. A evolução do DNA teria reduzido a taxa de mutação, ou a teria levado à redução (RIDLEY, 2007, p. 552).

Observa-se que a grande maioria dos vírus que infectam organismos eucarióticos multicelulares atuais são vírus de RNA. Isso se deve, conforme Hartman (2000, 


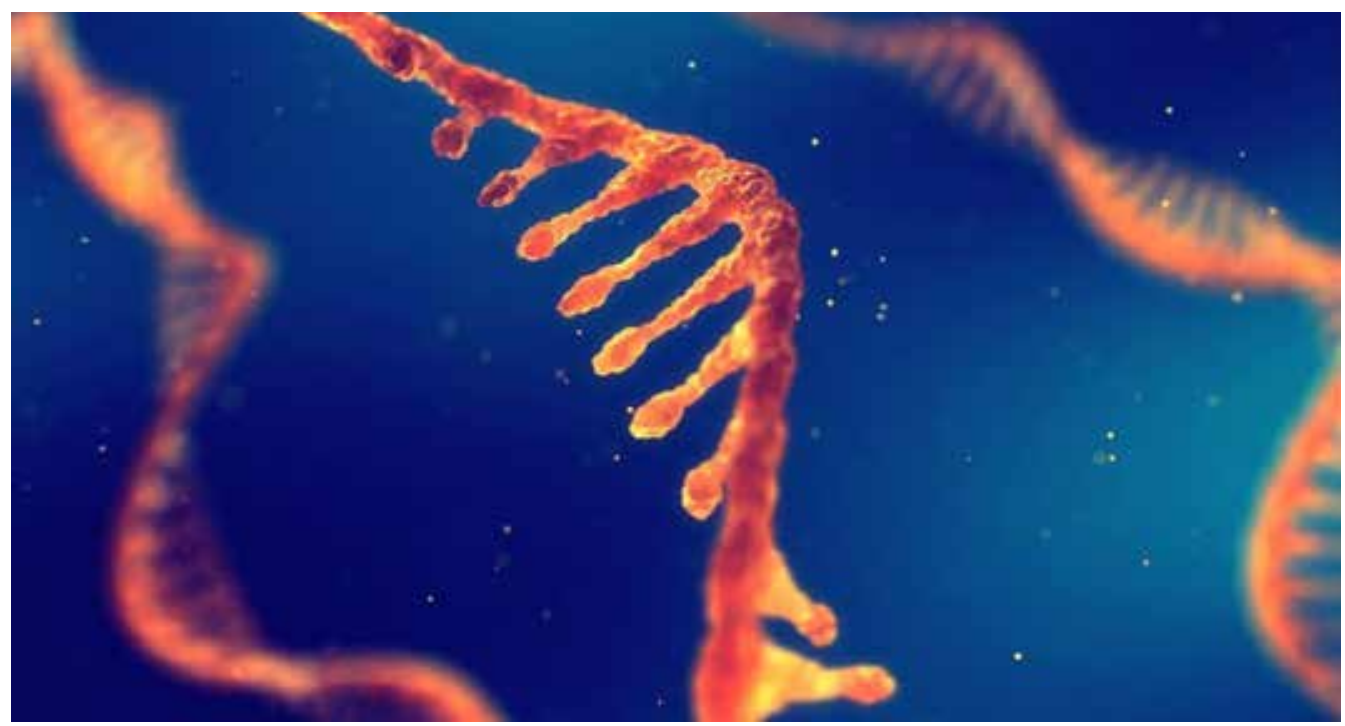

Denomina-se mundo do RNA uma fase hipotética primordial da vida na qual o RNA seria a molécula da hereditariedade

p. 235), aos remanescentes do sistema genético de uma célula de RNA primitiva. Atualmente os vírus de RNA apresentam maior diversidade, ocupando quatro dos sete grupos de vírus propostos por Baltimore, que "desenvolveu um esquema de classificação de vírus baseado na relação entre o genoma viral e seu RNAm” (MADIGAN et. al., 20I6, p. 266).

A tese do mundo do RNA, apenas explanatória, segundo a qual a molécula e seu respectivo ambiente favorecem o desenvolvimento de compostos orgânicos mais complexos, é questionada. Hartman (2000, p. 240) aponta dois problemas fundamentais nessa tese: o primeiro seria a improbabilidade de surgirem bases nitrogenadas na sopa primitiva, sintetizadas de maneira aleatória em uma atmosfera redutora contendo metano, amônia e hidrogênio; e o segundo, ainda mais questionável, é a suposição de que, com base em evidências geoquímicas, a atmosfera primitiva seria constituída de nitrogênio e dióxido de carbono. Por conseguinte, as descargas elétricas não teriam conduzido quaisquer compostos orgânicos, logo, não haveria sopa primitiva e, portanto, nenhum mundo de RNA.

Outrossim, Hartman levanta a problemática de uma entidade química ser capaz de replicação, sofrer mutação e ao mesmo tempo catalisar reações químicas. São elementos apontados para os quais ainda não se tem respostas definitivas. Como suposta explicação para tal imbróglio, sustenta-se que, enquanto o mundo de RNA tem fitas unidimensionais, o "mundo de argila" "II teria placas de duas dimensões. As argilas replicativas seriam catalisadores e não requereriam um mundo complexo de compostos químicos orgânicos.

11 Essa tese foi popularizada pelo livro Seven clues to the origin of life: a scientific detective story, de Alexander Graham Cairns-Smith, um químico que a desenvolvia desde meados dos anos 1960. Para o autor, existia uma etapa intermediária entre o mundo não vivo e o mundo vivo, em que a matéria orgânica se originava da replicação de cristais argilosos. 


\section{A tese de Richard \\ Dawkins sustenta \\ que a seleção \\ operaria no nível da \\ informação genética, \\ que se constitui de \\ invariantes químicos \\ das principais \\ macromoléculas}

Outra hipótese para o surgimento dos vírus sugere que "os vírus eram células que, por alguma razão, talvez para economizar seus genomas, descartaram tantos genes que se tornaram dependentes de um hospedeiro para a maioria das suas funções de replicação" (MADIGAN et. al., 20I6, p. 267).

Isso posto, as diferentes hipóteses para explicar a origem da vida até aqui aventadas nos levam a conceber uma entidade primordial acelular, cuja composição molecular teria sido formada na sopa primitiva, cuja água exerceria um suporte material para as reações químicas. Essas entidades ainda teriam a capacidade de se replicar, o que nos induz a pensá-las como pertencentes a um estágio anterior ao dos vírus, ou, supostamente, aos próprios vírus. Ainda assim, a questão de como os vírus surgiram permanece sem resposta. Uma possível hipótese para o segundo questionamento seria:

Um provável controlador da evolução viral foi como um mecanismo para as células rapidamente moverem genes na natureza. Uma vez que os vírus apresentam uma forma extracelular que protege o ácido nucleico dentro deles, eles poderiam ter sido selecionados como um meio de enriquecimento da diversidade genética (e, portanto, aptidão) de células, facilitando a transferência gênica entre elas (MADIGAN et. al., 2016, p. 268).

Essa função parece ser relevante para Madigan et. al. (20I6, p. 268), uma vez que trocaria de forma horizontal os genes entre células, especialmente entre os procariotas, o que soaria como um fator importante na evolução biológica. Além disso, manter o hospedeiro seria uma estratégia importante para o próprio vírus, sendo possível que os primeiros fossem latentes. Para os autores, as capacidades líticas só evoluiriam mais tarde, para ter acesso mais rapidamente a novos hospedeiros.

Por sua natureza, os vírus possuem informações codificadas em seus genes que permitem controlar processos vitais quando estão parasitando uma célula hospedeira. Nessa etapa bem delimitada, se aproximam do aspecto estrutural e funcional dos organismos vivos, ou se integram a eles, ao atingir suas células, utilizando-se do seu metabolismo para se reproduzirem. Essa capacidade só foi possível pelo conteúdo informacional guardado em seus genes e sua respectiva evolução biológica, além de uma estrutura capsular que protegeu essa informação ao longo do tempo e gerou 
descendentes com material genético modificado evolutivamente, o que nos faz recorrer à tese do gene egoísta defendida por Richard Dawkins.

A tese de Richard Dawkins sustenta que a seleção operaria no nível da informação genética, que se constitui de invariantes químicos das principais macromoléculas. O DNA ou RNA e suas proteínas associadas, como base molecular e informacional da vida, estão presentes em todos os seres vivos. Meyer e El-Hani (2000, p. I7I) afirmam que, "quando nos deparamos com semelhanças tão globais, a melhor forma de explicá-las é através da ancestralidade comum". Com isso, justifica-se a partilha dos invariantes tão comuns entre os organismos.Esses invariantes, conforme Monod (I97I, p. II9), constituíam uma ambição platônica na pesquisa sistemática anatômica que foi se consolidando a partir do ano de I950, com várias publicações acerca da química celular.

Importa assinalar que, embora esses invariantes químicos, por si sós, não confiram uma unidade morfofisiológica capaz de "deter todas as propriedades e o ponto de partida de todo organismo" (JACOB, I983, p. I24), eles, por sua vez,se estabeleceram como elo comum, se não a quase totalidade dos organismos em uma teia de grupos polifiléticos hiper-ramificados que, em algum momento na história evolutiva do mundo vivo, supõe-se compartilharem os mesmos mecanismos de replicação da molécula capaz de guardar a informação genética e perpetuar sua existência, ainda que através das sucessivas mutações.

Destarte, as mutações ocorridas no pool gênico fazem parte das estratégias evolutivas que conferem variabilidade aos vírus, sendo então submetida cada variação ao crivo das pressões seletivas. A variabilidade é um dos resultados das mutações genéticas e se constituiu emum dos mecanismos da evolução biológica, contribuindo na explicação da origem e diversidade da vida, principalmente a partir de meados do século XVII, quando ainda imperava o fixismo, doutrina que estabelecia a imutabilidade das espécies, explicada pelo poder divino, sem que ocorressem mudanças significativas na sua descendência.

Contudo, certa diversidade expressa nos vírus levanta um paradoxo na manutenção da estrutura invariante. A solução se daria pela própria constituição desse invariante biológico fundamental que é o DNA, formado por nucleotídeos e proteínas, cujos arranjos estabelecem um código genético que orienta a formação de fenótipos específicos e, consequentemente, submete-os às pressões seletivas.

Importante frisar que a reflexão sobre os invariantes voltados aos vírus não deve ser associada à defesa do reducionismo metodológico proporcionado pelos avanços da biologia molecular e celular. O que se está propondo é uma linha comum de abordagem a esses invariantes, com fins de integrar a diversidade da vida considerando seus níveis de organização, a informação genética, a história evolutiva dos organismos, a simbiose e as propriedades emergentes. Essa integração se expressa em funções biológicas importantes dos organismos, capazes de criar ordem na desordem e assim agirem de forma neguentrópica na luta pela vida. 


\section{0 VÍRUS E A SELEÇ̃̃O NATURAL DE REPLICADORES}

Com os pressupostos estabelecido se verificados pela biologia, definir vida com base nas análises feitas sobre os vírus, nos leva a contestar a visão tradicional sobre a definição de vida apregoada pelo biólogo evolucionista Ernst Mayr, a qual enumera "uma lista de propriedades definidoras do que ele chama de "processo de viver" (MAYR, 2008, p. 20), com uma visão de vida como seleção natural de replicadores oriunda das ideias de Richard Dawkins e complementada por David L. Hull (I935-20IO), filósofo estadunidense dedicado particularmente ao estudo da filosofia da biologia.

Desse modo, o termo replicador foi inicialmente utilizado por Dawkins (2007, p. 59) ao se referir a uma molécula como matriz, capaz de produzir cópias de si mesma e que no surgimento da vida reunia pequenos blocos moleculares ${ }^{12}$ de construção, que se achavam dispersos na sopa primordial. A estabilidade do replicador conferia-lhe aptidão para se sobrepor às contingências de uma possível desestruturação. Essas contingências seriam então consideradas pressões seletivas, sobre as quais operariam os mecanismos da evolução, causando uma seleção diferencial dos "mais aptos" (DAWKINS, 2007, p. 46). O autor, entretanto, analisa o conceito de seleção de grupo e o reconfigura para seleção no nível de gene (replicadores), chamando a atenção para a preservação de sua estrutura através das "máquinas de sobrevivência" ao longo do tempo, como células, indivíduos etc.

Sabe-se que a seleção natural atua produzindo adaptações, conforme as contingências do meio e as interações evolutivas ocorridas com o organismo, que se expressam em variabilidades gênicas e fenotípicas, e, por conseguinte, produz consequências para diferentes unidades, aqui entendidas como aquelas dispostas na hierarquia dos diferentes níveis de organização da vida, já consolidadas na biologia

12 Ridley (2007, p. 551) considera esses blocos como tijolos das construções moleculares da vida e se refere a eles como aminoácidos, açúcares e nucleotídeos. 
como as que se iniciam na célula, a menor unidade morfofisiológica do ser vivo, até a biosfera. Tais consequências irão ocasionar adaptações que, por sua vez, beneficiarão de forma imediata ou remota algum ou alguns desses níveis de organização, fruto das pressões seletivas da evolução.

Mayr (2005, p. I50) se referiu a tais unidades como alvos ou objetos de seleção, atribuição que ele considera errônea, uma vez que no processo de seleção natural os indivíduos eliminados eram os verdadeiros alvos da seleção, e não os que restavam. Assim, Ridley (2007, p. 332), ao analisar qual ou quais unidades seriam os alvos da seleção natural, afirma que "as unidades da natureza que apresentam adaptações são aquelas que mostram herdabilidade”. Como resultado, essas adaptações expressariam os ajustes das frequências gênicas.

Assim, o pensamento da vida como seleção natural de replicadores, ou entidades com capacidade de fazer cópias de si mesmas, é proveniente da biologia evolutiva neodarwinista, cuja explicação para os processos atinentes à vida se pauta pelas "linhagens de organismos conectados pelos processos de reprodução e seleção" (EMMECHE; EL-HANI, 200o, p. 43).

Conforme Dawkins, os genes se reúnem através de seus blocos construtores como unidades genéticas estáveis que atingem sua "imortalidade potencial" através de cópias de si mesmos. E sua eleição, para ser bem sucedidos como unidades de seleção natural, se dá por propriedades como "longevidade, fecundidade e fidelidade de cópia" (DAWKINS, 2007, p. 89). Com isso, esses genes teriam capacidade de produzir boas máquinas de sobrevivência, mesmo que venham a competir com seus alelos no pool gênico, processo esse considerado por Dawkins como unidade básica do egoísmo.

No caso do vírus, a máquina de sobrevivência seria o organismo formado pelo invólucro, englobando os principais blocos construtores - nucleotídeos, aminoácidos e proteínas - , mesmo que não consigam metabolizar substâncias de forma autônoma, como fazem as células. Essa estrutura confere ao vírus capacidade replicativa, com potencial evolutivo de transmissibilidade através de fluxo gênico entre células, como ilustra Ridley (2007, p. 644) ao abordar a coevolução de hospedeiro e parasita e, em outro momento, a evolução da virulência parasítica observada e depois experimentada em laboratórios. Esse experimento tratava do declínio da virulência em coelhos da Austrália e da Europa com mixomatose, doença causada pelo vírus Mixoma. O declínio foi supostamente atribuído a dois fatores combinados: o aumento da resistência do hospedeiro e a diminuição da virulência viral, tendo, graças à seleção natural, a capacidade de favorecer uma virulência mais alta ou mais baixa, dependendo do modo de transmissão do parasita.

Nesse sentido, a abordagem da vida como seleção natural de replicadores instigada por Dawkins é complementada, conforme Emmeche e El-Hani (2000, p. 44), pela visão do filósofo americano David Lee Hull'³, que propôs uma visão na qual não

13 Hull teve especial interesse pela filosofia da biologia, principalmente ao defender a tese de que espécies são indivíduos históricos, e também pelo processo de seleção natural, ao trocar o termo veículo, utilizado por Dawkins, por interactor. 
só os replicadores se mostram importantes, mas também os interagentes e as linhagens no processo evolutivo. Tal conceito veio à tona no caloroso debate sobre unidades de seleção, as quais Dawkins atribuía aos genes, num sistema biológico em que o organismo seria apenas o veículo dos replicadores. Hull (I980 apud MAYR, 2005) percebeu a inadequação do termo veículo por considerar que o objeto de seleção interage "como um todo coeso com seu ambiente".

Contra o argumento defendido por Dawkins, Hull observou que replicadores sozinhos, ou replicadores e veículos, seriam suficientes para a seleção. Nesse sentido, conforme Hull (200I, p. 23), a seleção pode ser caracterizada geralmente como qualquer processo em que a extinção e proliferação diferencial de interagentes causa a perpetuação diferencial dos replicadores que os produziram.

Como definição,

os interagentes são quaisquer entidades que interagem como um todo com o ambiente [..., cujo sucesso adaptativo, frente às pressões seletivas com as quais se defrontam em cada circunstância ambiental, determina as chances de os replicadores passarem cópias para a próxima geração (EMMECHE; El-HANI, 200o, p. 44).

Os interagentes teriam propriedades e habilidades que capacitariam os replicadores, mediante o sucesso reprodutivo e adaptativo, a repassar seus genes para as próximas gerações, e assim sucessivamente com as suas linhagens. Ou seja, a ação por si só dos replicadores, como Dawkins apregoa, ficaria igualmente comprometida caso os interagentes não dispusessem de condições para passar pelo crivo das pressões seletivas. Hull vê nessas entidades (replicantes e interagentes) uma condição indissociável para o processo da evolução natural, que se dá, de acordo com Emmeche e El-Hani (2000, p. 45), "exatamente por causa da ação recíproca da replicação da informação genética e da interação dos organismos com o meio ambiente".

De acordo com Mayr (2005, p. I49) o termo interagente possui algumas deficiências, sendo muito mais pertinente para a biologia funcionalista do que para a biologia evolutiva, e, nesse caso, não seria comum a interação durante o processo de eliminação que ocorre na seleção natural. Além disso, o autor despreza a produção de variação que ocorre durante a meiose e a própria produção. Entendemos, no entanto, que mesmo que a seleção natural exerça suas pressões sobre as variações, a eliminação de algumas destas só ocorre porque foi por meio da interação que a seleção natural pôde atuar. Isso pode ser confirmado por Hull (I976 apud ALVES 


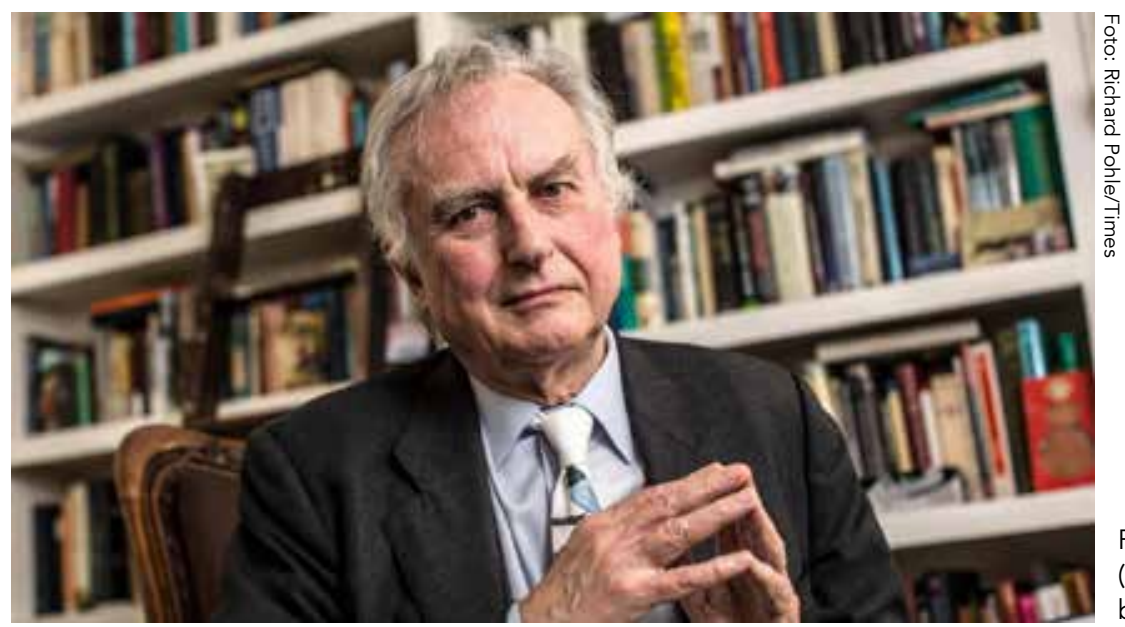

Richard Dawkins (1941), biólogo britânico

NETO, 20I3, p. 5I), quando ele estabelece como requisito que as unidades de evolução possam alterar substancialmente suas configurações genéticas antes de ser extintas ou dar origem a uma nova unidade.

Ademais, as linhagens a que Hull se refere comportam tais variações, ocorrendo como fruto da relação entre os replicadores e os interagentes, cuja informação genética foi acumulada ao longo das gerações. Ou seja, "a relação entre replicação e interação produz mudanças contínuas e se acumula, gerando padrões fenotípicos e genotípicos observáveis ao longo de inúmeras gerações. Essas linhagens e teias são as unidades de evolução" (HULL, I976, p. I82 apud ALVES NETO, 2013, p. 50).

Complementarmente à visão de Dawkins, orientada por uma visão informacional da vida, Emmeche e El-Hani (2000, p. 45) agregam aspectos organizacionais $e$ materiais. Para esses autores, somente uma concepção de replicadores como padrões de informação que se autopropagam sem adicionar esses dois aspectos levaria a uma concepção idealista, na qual a vida seria definida como qualquer realização de algum conjunto específico de propriedades informacionais abstratas, não importando o meio material. Nesses termos, um organismo simulado na tela de um computador poderia ser considerado tão vivo quanto os organismos constituídos por matéria orgânica com os quais estamos acostumados (EMMECHE; El-HANI, 200o, p. 45).

O aspecto organizacional vai ao encontro dos processos químicos, físicos e biológicos diferenciados da matéria inanimada e se expressa em todos os seus níveis, que se consolidam através do seu metabolismo, coordenação, interação, controle, história evolutiva, homeostase, propriedades emergentes etc. A organização no mundo vivo atende a um "princípio interno de desenvolvimento [...] e confere propriedades singulares" (JACOB, I983, p. 94), que vão desde a estrutura molecular, com unicidade bioquímica e grande potencial para a diversidade, até os grandes sistemas complexos na hierarquia da vida. Mayr (2008, p.45) atribui à organização 
um dos fenômenos específicos dos seres vivos, tendo os organismos vivos como sistemas ordenados e complexos, com capacidade de regulação e de controle da interação do genótipo, bem como seus limites evolutivos e de desenvolvimento.

Nesse seguimento, de acordo com Andrade (20I2, p. 99), o princípio da auto-organização, expresso no autoacoplamento estrutural e sua permanente interação com o meio circundante, dita uma mudança estrutural contínua e ao mesmo tempo conserva a reciprocidade da relação de transformação entre o organismo e o meio. Esse aspecto da autopoiese concebido por Maturana e Varela "refere-se a uma produção contínua de si mesmo pela vida" (MARGULIS; SAGAN, 2002, p. 3I), através do metabolismo que exerce esse papel continuamente por meio das reações químicas, provendo a autossustentação do sistema autopoiético. Assim, os sistemas vivos se configurariam como sistemas autopoiéticos, firmando-se nas interações moleculares organizacionalmente fechadas, mas abertas em termos materiais e energéticos, mediadas por moléculas informacionais que se auto-organizam diante das contingências histórico-evolutivas.

Conforme Eigen (I997, p. I8), a diferença entre um sistema químico, mesmo complexo, acoplado de maneira arbitrária, e um ser vivo, em que encontramos uma abundância de reações químicas, é que essas reações seguem um programa controlado, operado por uma central de informação, cuja meta é a autorreplicação de todos os componentes desse sistema, incluindo a duplicação do próprio programa ou, mais precisamente, da matéria que o contém.

À vista disso, diante do conceito de organização no mundo vivo, vislumbram-se, conforme Jacob (I983, p. 94), algumas consequências, como a que diz respeito à totalidade do organismo diante de um conjunto integrado de funções; e, dessa forma, só se poderão conferir às partes valor e importância desiguais quando nos referirmos à totalidade.

Outra consequência presumida ainda no século XVIII foi a de que o ser vivo não é uma estrutura isolada do seu meio; antes, insere-se na natureza, com a qual estabelece diferentes relações. Dentre essas relações, sublinhamos as de troca (de nutrientes, energia, calor...), uma vez que parte da matéria que compõe o mundo orgânico está presente no mundo inorgânico e assim forma ciclos biogeoquímicos importantes para fazer circular a matéria e energia entre os diferentes compartimentos da natureza.

E por fim, com base em Pallas, Lamarck, Vicq d'Azyr, De Jussieu e Goethe (apud JACOB, 1983, p. 93-94), redistribuem-se os organismos não mais em dois grupos, mas em seres inorgânicos ou minerais (não vivos, inanimados e inertes) e seres orgânicos, estes que se sujeitam à morte. 


\section{Tratar do conceito de vida}

a partir da problemática do

vírus torna-se desafiador

para a filosofia da biologia,

uma vez que essas entidades

se situam, conforme as bases

conceituais formuladas na

biologia, na fronteira entre o

mundo vivo e o não vivo

\section{CONSIDERACÕES FINAIS}

Os vírus, embora tenham potencial para causar doenças e possivelmente a morte dos indivíduos infectados, como se observa na pandemia da covid-ı9, não podemos excluí-los do processo evolutivo e tampouco da "cooperação" na dinâmica da diversidade biológica causada pelos processos de interação e compartilhamento da informação genética através dos seus interagentes.

Tratar do conceito de vida a partir da problemática do vírus torna-se desafiador para a filosofia da biologia, uma vez que essas entidades se situam, conforme as bases conceituais formuladas na biologia, na fronteira entre o mundo vivo e o não vivo, e as propriedades operacionais utilizadas razoavelmente por essa disciplina demarcam tal fronteira. No entanto, recorrer aos aspectos da origem da vida, do mundo do RNA, pode nos direcionar a uma estratégia argumentativa cabível para explicar os vírus do presente e sua "localização e/ou inclusão" nos níveis de organização da vida.

Nesse sentido, a concepção de Dawkins sobre o gene como replicante, embora possa recorrer a um aspecto de cunho reducionista da vida, não necessariamente se encerra nele, motivo pelo qual lançamos mão do fisicalismo não redutivo como tese filosófica para contemplar o domínio autônomo de macropropriedades, irredutíveis às micropropriedades.

A problematização do conceito de vida, tendo por base os replicantes e interagentes, bem como a situação do vírus na organização da vida, possibilita-nos perceber que a reunião desses aspectos consolida uma visão sobre sistemas vivos numa perspectiva evolucionista darwiniana, e por conseguinte afloram elementos teóricos razoáveis para endossarmos um conceito de vida nas ciências biológicas com base numa molécula replicativa, informacional e todo o seu conjunto interativo que se or- 
ganiza formando propriedades intrínsecas e emergentes em todos os níveis da vida, considerando-se as contingências do meio e seus processos histórico-evolutivos.

Assim sendo, discorrer sobre tal problemática requer alicerces pautados pela evolução, nas ciências, na biologia e na filosofia de forma mais ampla, ao mesmo tempo integradas no espectro interdisciplinar, dado que essas áreas contemplam conhecimentos voltados à formação de conceitos nos quais a própria biologia se apoia e se desenvolve como disciplina autônoma.

Essas reflexões se mostram fundamentalmente necessárias, uma vez que o objeto empírico central da biologia é a vida, cujos processos em sua grande maioria são perceptíveis e mensuráveis, e conceituá-los, numa perspectiva abrangente e integrada, assente na concepção de replicantes e interagentes, conjuntamente com os processos evolutivos, mostra-se contributo para a definição de um conceito de vida no âmbito da biologia.

* Professor assistente da Universidade Federal do Maranhão (UFMA), campus de Pinheiro. Graduado em Ciências Biológicas e mestre em Sustentabilidade de Ecossistemas pela UFMA. Especialista em Educação Ambiental pela Universidade Estadual do Maranhão (Uema). Doutorando em Filosofia pela Universidade Estadual do Rio de Janeiro (Uerj).E-mail: roberto.ramos@ufma.br

Texto recebido em 25 de março de 2021; aprovado em 11 de junho de 2021. 
ABRANTES, Paulo. C. Introdução: o que é filosofia da biologia? In: et al. (Org). Filosofia da biologia. 2. ed. Rio de Janeiro: Seropédica; PPGFIL-UFRRJ, 2018.

ALVES NETO, Celso Antônio. O estatuto ontológico das espécies biológicas na sistemática filogenética. 2013. 148 p. Dissertação (Mestrado em Filosofia) - Faculdade de Filosofia e Ciências Humanas, Universidade Federal de Minas Gerais, Belo Horizonte, 2013.

ANDRADE, Claudia Castro de. A fenomenologia da percepção a partir da autopoiesis de Humberto Maturana e Francisco Varela. Griot: Revista de Filosofia,v. 6, n. 2, 2012. p. 98-121.

BRANDÃO, Raul Emanuel Lopes. Vírus e retrovírus: contributo para a evolução das espécies. Dissertação(Mestrado em Ciências Farmacêuticas) - Faculdade de Farmácia, Universidade Fernando Pessoa, Porto, Portugal, 2015.

CAMPBELL, Neil; REECE, Jane B. Biologia. 8. ed. Porto Alegre: Artmed, 2010.

CORRÊA, André Luís et. al. Aspectos históricos e filosóficos do conceito de vida: contribuições para o ensino de biologia. Filosofia e História da Biologia, São Paulo, v. 3, 2008. p. 21-40.

DAHLBERG, Ingetraut. Teoria do conceito. Ciência da Informação. Rio de Janeiro, v. 7, n. 2, 1978. p. 101-107.

DAWKINS, Richard. O gene egoísta. Tradução Rejane Rubino. São Paulo: Companhia das Letras, 2007.

EIGEN, Manfred. O que restará da biologia do século XX? In: MURPHY, Michael P.; O’NEILL, Luke A. J. (Org.). O que é vida?: 50 anos depois - especulações sobre o futuro da biologia. São Paulo: Editora Unesp, 1997. p. 13-33.

EL-HANI, Charbel Niño. Níveis da ciência, níveis da realidade: evitando o dilema holismo/reducionismo no ensino de ciências e biologia. 377 f. Tese (Doutorado em Educação) — Faculdade de Educação, Universidade de São Paulo, São Paulo, 2000.

EMMECHE, Claus; EL-HANI, Charbel Niño. Definindo vida. In: EL-HANI, Charbel Niño; VIDEIRA, Augusto Passos. O que é vida?: para entender a biologia do século XXI. Rio de Janeiro: Relume Dumará, 2000. p. 31-56.

FIOCRUZ. Qual a origem desse novo coronavírus? Rio de Janeiro: Fiocruz; Ministério da Saúde, s.d. Disponível em: <https://portal.fiocruz.br/pergunta/qual-origem-desse-novo-coronavirus>. Acesso em: 6 ago. 2020.

GOULD, Stephen Jay. O que é vida? como um problema histórico. In: MURPHY, Michael. P.; O’NEILL, Luke A. J. (Org.). O que é vida?: 50 anos depois - especulações sobre o futuro da biologia. São Paulo: Editora Unesp, 1997. p. 35-51.

HARTMAN, Hyman. Vírus, evolução e origem da vida. In: EL-HANI, Charbel Niño; VIDEIRA, Augusto Passos. O que é vida?: para entender a biologia do século XXI. Rio de Janeiro: Relume Dumará, 2000. p. 233-242.

HULL, David Lee. Science and selection essays on biological evolution and the philosophy of science. Cambridge: Cambridge University Press, 2001.

JACOB, François. A lógica da vida: uma história da hereditariedade. Rio de Janeiro: Graal, 1983.

LLOYD, Geoffrey Ernest Richard. Aristotle: the growth \& structure of his thought. Cambridge: Cambridge University Press, 1968.

MADIGAN, Michael T. et al. Microbiologia de Brock. Tradução Alice Freitas Versiani. 14. ed. Porto Alegre: Artmed, 2016.

MARGULIS, Lynn; SAGAN, Dorion. O que é vida?. Rio de Janeiro: Jorge Zahar, 2002.

MAYR, Ernest. Biologia, ciência única: reflexões sobre a autonomia de uma disciplina científica. Tradução Marcelo Leite. São Paulo: Companhia das Letras, 2005. 
Isto é biologia: a ciência do mundo vivo. São Paulo: Companhia das Letras, 2008.

MATURANA, Humberto VARELA, Francisco. A árvore do conhecimento: as bases biológicas do entendimento humano. São Paulo: Psy II, 1995.

De máquinas y seres vivos: autopoiesis, la organización de lo vivo. 1. ed. Buenos Aires: Lumen, 2003.

MEYER, Diogo; EL-HANI, Charbel Niño. Evolução. In: EL-HANI, Charbel Niño; VIDEIRA, Augusto Passos. O que é vida?: para entender a biologia do século XXI. Rio de Janeiro: Relume Dumará, 2000. p. 153-185.

MONOD, Jacques. O acaso e a necessidade. 2. ed. Rio de Janeiro: Vozes, 1971.

NUNES, Luiz R.; OLIVEIRA, Regina Costa. Replicação do DNA. In: EL-HANI, Charbel Niño; VIDEIRA, Augusto Passos. O que é vida?: para entender a biologia do século XXI. Rio de Janeiro: Relume Dumará, 2000. p. 139-151.

OPARIN, Aleksandr. A origem da vida. São Paulo: Escriba, 1955.

PAPINEAU, David. The rise of physicalism. In: STONE, M. W. F.; WOLFF, Jonathan (Ed.). The proper ambition of science. London: Routledge, 2000. p. 174-208.

RIDLEY, Mark. Evolução. 3. ed. Porto Alegre: Artmed, 2007.

RUIZ-MIRAZO, Kepa; PERETÓ, Juli; MORENO, Alvaro. A universal definition of life: autonomy and open-ended evolution. Origins of Life and Evolution of the Biosphere, n. 34, Netherlands: Kluwer Academic Publishers, 2004. p. 323-346.

SADAVA, David et. al. Vida a ciência da biologia. 8. ed. Porto Alegre: Artmed, 2009.

SCHRODINGER, Erwin. O que é vida?: o aspecto físico da célula viva, seguido de "Mente e matéria" e "Fragmentos autobiográficos". São Paulo: EditoraUnesp, 1997.

STOLJAR, Daniel. Physicalism. In: STANFORD encyclopedia of philosophy. Disponível em: <https:// plato.stanford.edu/entries/physicalism>. Acesso em: 11 jun. 2019. p. 1-67.

VIEYRA, Adalberto e SOUZA-BARROS Fernando. Teoria da origem da vida no século XX. In: EL-HANI, Charbel Niño ; VIDEIRA, A. P. O que é vida? para entender a biologia do século XXI. Rio de Janeiro: Relume Dumará, 2000. p. 71-101.

WEBER, Bruce. Life. In: STANFORD encyclopedia of philosophy. 2015. Disponivel em: <https:// plato.stanford.edu/entries/life >. Acesso em: 16 fev. 2021.

ZILIO, Diego. Fisicalismo na filosofia da mente: definição, estratégias e problemas. Ciências \& Cognição, v. 15, n. 1, 2010. p. 217-240. 